\title{
Problem-Based Learning in Teaching of Thanatology in Undergraduate Nursing Program
}

\author{
Aprendizagem baseada em problemas no ensino da Tanatologia, no curso de graduação em \\ Enfermagem \\ Aprendizaje basado en problemas en la enseñanza de la Tanatología en el curso de graduación \\ en enfermería
}

\author{
Cynthia Lima Sampaio ${ }^{1}$ \\ Maria Fabiana de Sena Neri ${ }^{1}$ \\ Michell Ângelo Marques Araújo ${ }^{1}$ \\ Joselany Áfio Caetano ${ }^{1}$ \\ Suzana Mara Cordeiro Eloia ${ }^{1}$ \\ Ângela Maria Alves e Souza ${ }^{1}$
}

1. Universidade Federal do Ceará.

Fortaleza, CE, Brasil.

Corresponding author:

Cynthia Lima Sampaio.

E-mail: cyliss@hotmail.com

Submitted on $03 / 07 / 2018$.

Accepted on 05/04/2018.

DOI: 10.1590/2177-9465-EAN-2018-0068

\begin{abstract}
Objectives: To report a methodological experience of learning-based on problems in the discipline of Thanatology. Method: Experience report of professors of the baccalaureate degree in nursing using problem situations influenced by the methodology of questioning and problem-based learning. Results: The elaboration of three problem situations broadened the development of the formative process in Thanatology, favored reflections during the program of the discipline and approached the theory of real situations experienced by the students. Conclusions and implications for practice: This methodology was assessed as a viable and low-cost strategy in promoting empowerment on issues of death and dying. In addition, students self-assessed as reflective agents and builders of their own personal and professional growth.
\end{abstract}

Keywords: Nursing Education; Problem-Based Learning; Thanatology; Teaching; Nursing.

\section{Resumo}

Objetivos: Relatar uma experiência metodológica de aprendizagem, baseada em problemas, na disciplina de Tanatologia. Método: Relato de experiência de docentes do curso de bacharelado em Enfermagem, ao utilizar situações-problema influenciadas pela metodologia da problematização e aprendizagem baseada em problemas. Resultados: A elaboração de três situações-problema ampliou o desenvolvimento do processo formativo em Tanatologia, favoreceu reflexões no decorrer da disciplina e aproximou a teoria de situações reais vivenciadas pelos alunos envolvidos. Conclusões e implicações para a prática: Considera-se estratégia viável e de baixo custo promover o empoderamento quanto às questões sobre morte e morrer. Além disso, os alunos se avaliaram como agentes reflexivos e construtores do próprio crescimento pessoal e profissional.

Palavras-chave: Educação em Enfermagem; Aprendizagem Baseada em Problemas; Tanatologia; Ensino; Enfermagem.

\section{Resumen}

Objetivos: Relatar una experiencia metodológica de aprendizaje basada en problemas en la disciplina de Tanatología. Método: Relato de experiencia de docentes del curso de bachillerato en enfermería al utilizar situaciones-problemas influenciadas por la metodología de la problematización y aprendizaje basada en problemas. Resultados: La elaboración de tres situacionesproblemas amplió el desarrollo del proceso formativo en Tanatología, favoreció reflexiones en el curso de la disciplina y acercó la teoría de situaciones reales vivenciadas por los estudiantes. Conclusiones e implicaciones para la práctica: Esta metodología fue evaluada como una estrategia viable y de bajo costo al promover el empoderamiento en cuanto a las cuestiones sobre muerte y morir. Además, los estudiantes se autoevaluaron agentes reflexivos y constructores del propio crecimiento personal y profesional.

Palabras clave: Educación en Enfermería; Aprendizaje Basado en Problemas; Tanatología; la Educación; Enfermería. 


\section{INTRODUCTION}

Thanatology is an interdisciplinary science that focuses on the study of death and dying. In recent years, we have studied the process of death and dying, but it is still a challenge to accept the theme with naturalness and resilience. In addition, the phenomenon is influenced by age, physical problems, psychiatric conditions, ethnicity, religiosity, personalities, sociocultural experiences and beliefs. ${ }^{1}$

Nursing is a profession that cares for the human being throughout the life cycle and is also present at the time of death, whether in home care, hospital care or in emergencies. However, nurses have difficulties in attending patients with reserved and terminal prognosis, since the proximity of their death can generate impotence and guilt in the professional involved in the care. Death proves to be a failure, generating reactions and dysphoric feelings, such as sadness, deception, nonconformity, dissatisfaction, guilt, anxiety, depression, fragility, self-doubt, low self-esteem, injustice, helplessness, failure, impotence, anger or frustration. ${ }^{2}$

Nursing programs offer little space for discussion of Thanatology, leading to an incipient practice. Professors report a gap during the academic training and perpetuation of this practice due to the lack of theoretical preparation and small workload in the disciplines, with prioritization of nursing techniques and the care of the physical body, evidencing the need to approach the subject in an interdisciplinary and/or directed way, through complementary discipline. ${ }^{3}$

Changes in the paradigm of nursing education imply the requirement of professionals who, besides the technicalscientific knowledge, have the skills to deal with their own feelings and use them with humanized attention to the care provided to the patient and their family.

For this, the academy and health institutions need to develop skills in students and health professionals, not only in technical aspects, but in issues related to emotion, focusing on the terminality of life and the development of intervention that provokes changes in the relation of the subject with aversive changes of the environment and, consequently, adjustments for the confrontation of stressors associated with treatment of death. ${ }^{4,5}$ Critical thinking is one of the most important criteria related to the development of skills, which are intrinsic to the improvement of nursing professional practice. ${ }^{1}$

In Brazil, the Guidelines for Basic Education (Diretrizes de Bases da Educação) have been guiding changes that can make education more flexible, critical, reflective, constant and responsive to the health care challenges of the population and professional training. They point to the need to train professionals with competence to act with social responsibility, in addition to exercising the role of health promoters, based on the principles of the Brazilian Healthcare Reform (Reforma Sanitária Brasileira) and the Unified Health System (SUS - Sistema Único de Saúde). ${ }^{1}$

In order to reach humanization in the practices related to death and dying, valuing the subjects involved, as recommended by the Brazilian Humanization Policy (PNH- Política Nacional de Humanização), and a care of excellence, nurses need to articulate knowledge, to add them to their own life experiences, and face personal barriers (fear, anguish, trauma) and imposed by the system (overcrowding and lack of resources). This preparation should be started, still, in the undergraduate education, by discussions in group about this reality and the best way to face it and/or necessary referrals for logotherapy, etc. ${ }^{6}$

Knowing how to deal with the feelings of death is the starting point of this preparation, for as long as the theme is neglected from the real dimensions and meanings, it will be considered as something distant until the moment of confrontation with the finitude of oneself or of loved ones. ${ }^{7}$ The nurse, when he/she is confident of his/her emotions, recognizing limits and potentialities, is better prepared to deal with the suffering of the other, demonstrating sensitivity, support and identity of the role, without suffering by this conduct.

Faced with the need to train the critical, humanized nurse, confident about personal and professional emotions, the question arose: how to improve teaching in the discipline of Thanatology? Considering that it is a theoretical and practical learning, it was sought to use active learning methodologies for the development of skills in the student and the construction of the student's learning. Thus, this study aimed to report a methodological experience of learning based on problems in the discipline of Thanatology.

The use of Problem-Based Learning $(\mathrm{PBL})^{8}$ in the teaching of Thanatology can boost critical thinking, teamwork and reflection on the performance in the different settings of practice, as well as facilitate the discussion of various issues with comfort, palliative care, family and, consequently will contribute to more active, autonomous and dialogic training.

\section{METHOD}

It is an experience report of professors of the baccalaureate degree in nursing of a federal public university, using problem situations, influenced by the Methodology of Questioning and the PBL, adopted in the discipline of Thanatology, which is optional, with a workload of 32 hours divided into 16 meetings, addressing the contents: Spirituality and Mourning; History of death and Thanatology; Bioethics; Psycho-Oncology; Palliative care; Communication of bad news; and Suicide.

The discipline proposed the minimum gist of PBL: 1) the student as the core; 2 ) resolution of real-life problem situations; 3) learning process involving self-directed study and selfassessment; 4) curriculum composed of problems-content appropriate to the program; 5) professor as facilitator of the learning process; 5) group learning.

Nineteen students of the nursing program and one of the Psychology program held it in the first half of 2014. The teaching staff was made up of three professors of the nursing 
undergraduate, with the participation of a master's degree graduate program in nursing.

The planning of the learning process used in the program of Thanatology began in the year 2014. The group of professors met to discuss what should change in relation to the syllabus of the discipline and how could be implemented the necessary changes to adhere to the strategy of learning with problem situations. During the planning meetings, situations experienced were discussed by the master's student in the specialization in Activation of Processes of Change in Higher Education of Health Professionals, a program held in 2013, whose proposal was to work on problem situations in which students/professionals started to conduct autonomously the process of learning during the professional life, to exercise proactivity in the necessary changes, with critical sense, decision, humanistic vision and ethics. ${ }^{2,9}$ The experience of the masters in this specialization brought principles of the PBL methods and Questioning that collaborated with the transformation of contents of theoretical classes of Thanatology in problem situations.

The situations were elaborated with the objective of approaching challenges posed by the world of work, bringing regional cultural characteristics, elements of the unit's routine, interpersonal relations and participation of the multiprofessional team and the family in the hospital environment.

The problematic situations incorporated the questioning, allowing to analyze the characteristics by the Maguerez's Arch Method: observation of the reality (problem), attainment of key points, theory, hypotheses of solution and application to reality (practice); and the PBL method that allowed to work intentionally with problems elaborated by a team of professors to cover all the essential knowledge of the curriculum and explored the student participation and self-assessments of knowledge and abilities. ${ }^{10}$

Teaching strategies involved more than just "doing", but associating it with critical and reflective thinking in the face of learning situations. The key concept of this pedagogical model is to learn by doing, comprising an overlapping of "action-reflectionaction" on the traditional binomial theory/practice in the development of knowledge. This model integrates the current basic and clinical cycles, through the questioning, guiding the search for knowledge and skills that base the interventions, and working with the presented issues, both from the point of view of clinical and collective health. ${ }^{1}$

An advantage of the implementation of problem situations is the low cost for application, when compared to other commonly used active methodologies such as website, simulation, among others.

The experience of using problem situations as learning strategies for care in nursing in Thanatology is presented below. The processes of implantation of the problem situations are described, as well as the group discussion on the themes that have awakened the need for theoretical and reflexive subsidies.

\section{The operation of problem situations}

From the reading of the problem situations, the participants were invited to express previous knowledge, capturing the problem of the situation (first stage of the learning process). The group was encouraged to formulate hypotheses and/or explanations on the problem (second stage) and to elaborate learning questions aimed at checking and/or substantiating the hypotheses raised (third stage). Individual search and group discussion would allow the construction of new meanings based on the skills profile (fourth and fifth stages). ${ }^{11}$ The process was concluded by assessing the set of all these learning stages.

Thus, a text was read, opening the problem situation, then the students attained the key points and elaborated the learning issues, which consisted of a guiding question that contemplated all the participants. The students rehearsed a number of questions, until they reached agreement on an issue that covered all the key points listed. This moment motivated the participation of the group to research what was of interest, making learning meaningful.

In the second meeting of each problem situation the students shared how they performed the search and what they sought, developing theory on the subject. The facilitator had the role of instigating them to follow a line of reasoning that would lead to the answer of the question, preferably, by means of questions. Encouraging everyone to participate was essential. The professor moved from investor to activator and continued to coordinate the discussion to form a subsidy to elaborate a text covering the answer of the learning issue.

In the last class on each problem situation, the closing was accomplished, which consisted of complementing the previous discussion, clear and objective response of elements that responded to the synthesis, retrieval of the concepts learned and assessment of the closure of the problem situation. This assessment consisted of the students' speech about the acquired learning. They also delivered the syntheses that answered the learning issues, which were read and returned next class, with observations on the content and the exchange of information in the classroom.

In these meetings, students' experiences and facilitators emerged that allowed the visualization of the theoretical application in practice and personal lives, whether personal or professional. Research and discussion provided students with an understanding of what the mourning process is, how professional counseling should be, as well as the historical evolution of the concept of death and meaning for different cultures, professional practice in suicide care and palliative care. Thanatology, therefore, shows relevance in the nursing care in any field of care, since death and mourning are part of the care network as a natural consequence of life. The programs need to take place not only in the curricular educational process, but also as part of the orientation for the health team members and as permanent education in the institutions. ${ }^{4}$ 


\section{Building knowledge}

The problem situations were denominated by "Experiences of Mariana", "The internship of Cláudio" and "The project of Amanda and Sara", according to Figure 1.

The first problem situation brought the experience of a young Brazilian woman who was in Germany, through the Sciences without Borders program, and came across the cultural differences that govern a funeral. The students had an approximation to the Thanatology, examining cultural factors that influence the phenomenon of death, brought by them in the first contact. Yet, there is limited research in nursing that examines cultural and religious factors and their influences on the event of death along with comparative approaches among cultures. ${ }^{4}$

Each brought the aspect of the problem situation that stood out and sought to respond to the concerns (Chart 1). The stages of mourning and the differentiation of normal and pathological mourning were the best aspects seized by all involved, some students also brought interesting cultural particularities, individual experiences of losses and other subjects were worked on the following approaches. This emphasis can reduce the culture of death as a taboo for health professionals and enhance the quality of communications and thus perceptions of care among health professionals and patients and family members. ${ }^{4}$

Before starting the second problem situation, a visit was made, in loco, to two cemeteries of the city, one ancient and one more modern. The visit provided students with a knowledge of the rituals of death, relating to the history of death, the stages of mourning and spirituality, as well as the history of the city and the economic and artistic aspects. On the day of the last visit, in a comfortable place, the students were asked to draw and write what they would have written on the tombstone. The difficulty of recognizing themselves dead was almost general, at that moment they sensitized themselves to a reflection on their own finitude.

The second problem situation dealt with the experience of a student of the last semester of nursing undergraduate program who took care of a patient that tried suicide, with a reserved prognosis (Chart 2). The problem situation brought about quite complex aspects, but there was already a thematic approach with the discipline of Ethics and Legislation in Nursing. The students were then able to relate the disciplines and to deepen the practical aspects, mainly through the reporting of situations experienced by professors and students. At that moment, multidisciplinarity was presented through the rescue of the disciplines: Ethics, Epidemiology, Adult Care, Mental Health, besides the main focus, professional approach to suicide (Epidemiology, Risk Factors, Prevention and Conduct), demystifying the popular ideals. Also discussed were the concepts of euthanasia, dysthanasia, orthothanasia, social euthanasia and communication of bad news.
The ethics, emphasized in the Brazilian Curriculum Guidelines (Diretrizes Curriculares Nacionais) for nursing programs, must be understood through real and direct experiences, experienced in the daily services, permeating the development of curricular contents and establishing a dialogical relationship between students and professors. ${ }^{1}$

The last problem situation dealt with the care of patients with cancer carried out in the extension project with two students, one of nursing and one of psychology (Chart 3). Finally, the necessary skills for professional action were discussed with patients and families in the process of death and dying. The link and the ideal therapeutic relationship for care were widely debated.

During the third problem situation, after formulating the learning issue, the students were interviewed in the Laboratory of Alternative Health Practices, with adequate lighting, environment and sound, in which they adopted the role of companion and family member who receive the communication of bad news. At the moment of expressing the feelings about the experience, the emotion arose. The role of the sick was better accepted than that of the family by the majority. Particular situations with relatives, fears and anxieties were revealed and the group assumed the proper function of a therapeutic group, providing listening and support, as well as empathy and understanding of the pain of the loss.

These discussions are essential for the training of nurses, professionals who deal with daily death and who must meet the health needs of the population. However, professors and students, in fact, distance themselves from dialogue, from understanding the difficulties of the other, from completeness in the relationships established in the training process. ${ }^{12}$

\section{Self-assessment and group assessment}

At the end of the signature, they were asked to write a farewell letter. Some intended the letter to family, friends, lovers or both and others did not specify the recipient. Some did as if death were in the present moment and others in the distant future. Again, it was pointed out that there is no way to determine this day and that the sign of detachment is to write it as it were today.

The assessment was carried out through a portfolio, encompassing: expectations and choice of discipline; the report of how the construction of each learning issue, the search in the literature, the elaboration of the individual synthesis and the group sharing and debate; understanding and applicability of each learning issue to other disciplines; individual synthesis; assessment of each problem situation; individual, group and facilitator assessment; assessment of the discipline. The portfolios brought the path of the discipline, with particular reports of confrontation, more complete syntheses, taking into account the suggestions of the facilitator, photos, drawings, and new perspectives on Thanatology, presenting life and interest, but recognizing limitations, due to the need for continuous study, and absence of experiencing a certain situation. 
Figure 1. Presentation of problem situations. Fortaleza, Ceará State, Brazil, 2014.

\section{PS 1: Experiences of Mariana}

Mariana, a Brazilian student of the fourth semester of Nursing undergraduate course at the Universidade Federal do Ceará, is in Germany for the Science without Borders (Ciências sem Fronteiras) program. Throughout her six-month stay, she still notices cultural differences in many ways. Her neighbor, Mr. Schmidt, had passed away, and the family was receiving visits from friends and relatives who came from distant places. In offering her condolences, she was also invited to the ceremony. The funeral was held in the cemetery, where the body waited for a week the arrival of all in a cold room. In the funeral chapel, before the funeral began, a friend of Mr. Schmidt played a musical instrument. Then family and friends praised the deceased. The people who gave their condolences to his wife also handed him an envelope with a card and money. After the funeral, the family invited everyone to go to a restaurant. Mariana remembered the funeral of her three-year-old cousin, the only one who had been killed, and the behavior of her aunt Silvânia, who was prevented from participating because she was out of control, punishing herself for not having stopped the fact. She acts as if the daughter was to return and still keeps all the objects of the room the same way it was before that happened. Sometimes she remains isolated from the rest of the family and angry at everyone, even moving away from the church she used to go. Mariana thinks she should seek professional help and feels frustrated because she does not know what to do.

Syllabus: The following key concepts should be worked out in this SP: History of death, Mourning process (normal mourning and pathological mourning), Mourning counseling, Spirituality. They constitute the basic understanding of the study of death and dying, which will be complemented by the other PSs.

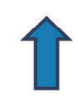

Program content: Spirituality and Mourning, History of Death and Thanatology, Bioethics, Psycho-Oncology and Palliative Care, Communication of Bad News and Suicide.

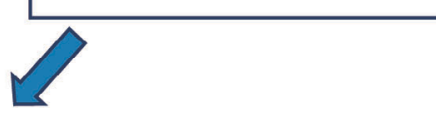

\section{PS 2: The internship of Cláudio}

Cláudio, student of the last semester of nursing undergraduate course, is having supervised internship at the Intensive Care Unit (ICU) of a reference hospital. He has witnessed the death of many seriously ill patients, but one particular case has intrigued him. Paulo, 17, who had suffered from bipolar disorder and was hospitalized for exogenous carbamate poisoning, was in a coma after the third suicide attempt. The multiprofessional team was reported on non-resuscitation, but nothing was clarified to the mother. Days later, Paul died shortly before the time of the visit. The mother was not communicated in time and was barred from visiting. The news was given abruptly and the family, unconfused, accused the team of having practiced euthanasia.

Syllabus: The key concepts should be seized: Death and dying, Communication of bad news, Bioethics, Euthanasia, Dysthanasia, Orthothanasia and Suicide. It allows the understanding of the actions and ethical and legal limits of professional practice.

\section{PS 3: The Project of Amanda and Sara}

Lúcia, 23 years old, was diagnosed with breast cancer with hepatic metastasis, and was admitted to Hospital das Clínicas for polychemotherapy and radiotherapy. Amanda, a nursing student, and Sara, a psychology student, participated in an extension project at the University, performing patient support activities. On a visit to the Unit of Hematology they found Lucy bored, but hopeful about the treatment. When searching to know about her clinical history in the medical record, they identified that the prognosis was negative and considered palliative care, but all the measures were being performed. Both were shaken by the possibility of the death of someone so young. At first, they were afraid to get emotionally involved with Lucia, but decided to get close to her and the other patients in the ward.

Syllabus: The key concepts should be discussed: PsychoOncology, Pain and professional suffering before death and own finitude and palliative care. It provides reflection on the possibilities of professional performance and on death itself. 
Chart 1. Key points and learning issues culminating in the problem situation entitled "Experiences of Mariana". Fortaleza, Ceará State, Brazil, 2014.

\begin{tabular}{|ll|}
\hline Key points & Learning issues \\
\hline $\begin{array}{l}\text { Blame, impotence, cultural differences, isolation, solidarity, } \\
\text { identification, homage to the deceased, denial, professional }\end{array}$ & How does coping with personal, family and professional \\
$\begin{array}{l}\text { performance, fear, pain, coping with mourning, spirituality, } \\
\text { religiosity, resilience. }\end{array}$ & grieving in different cultures occur? \\
\hline
\end{tabular}

Source: Created by the authors.

Chart 2. Key points and learning issues culminating in the problem situation entitled "The internship of Cláudio" Fortaleza, Ceará State, Brazil, 2014.

\begin{tabular}{|ll|}
\hline Key points & Learning issues \\
\hline $\begin{array}{l}\text { Communication of bad news, euthanasia, dysthanasia } \\
\text { and orthothanasia, when not reanimate, sensitivity and }\end{array}$ & How should the behavior of the professional in the face of \\
professional preparation before death, respect, barring the & $\begin{array}{l}\text { suicide, in the scope of bioethics, in relation to the patient } \\
\text { visit, suicide, bipolar disorder, clarification to the family }\end{array}$ \\
$\begin{array}{ll}\text { member, reception, prejudice of the professionals in relation } \\
\text { to suicide and the family. }\end{array}$ & \\
\hline
\end{tabular}

Source: Created by the authors.

Chart 3. Key points and learning issues culminating in the problem situation entitled "Amanda and Sara's Project". Fortaleza, Ceará State, Brazil, 2014.

\begin{tabular}{|ll|}
\hline Key points & Learning issues \\
\hline $\begin{array}{l}\text { Bonding, fear of being emotionally involved, therapeutic } \\
\text { relationship, fear of death, palliative care, suffering/finitude, } \\
\text { meaning of life, hope, age to die. }\end{array}$ & $\begin{array}{l}\text { What should be the therapeutic relationship of health } \\
\text { professionals with critically ill patients? }\end{array}$ \\
\hline
\end{tabular}

Source: Created by the authors.

There is difficulty in teaching Thanatology, due to numerous classes, small hours, and little age of students. However, the challenge faced with the number of students enrolled and the proposal different from what they were used to has been overcome, and the objectives have been achieved in a pleasurable way, corroborating with other publications that affirm that learning through active methodologies adds similar knowledge However, the student's performance in relation to the skills and attitudes is superior, as well as the greater satisfaction on the part of the academic ones, considering that the use of practical cases provides a greater relation with the reality, facilitating the fixation of contents and promoting critical thinking. ${ }^{4}$

\section{FINAL CONSIDERATIONS}

The teaching of Thanatology is a real necessity in the professional practice of nursing. students sought discipline for diverse interests, curiosity, personal need, credit to be met, and demonstrated interest, participation, commitment, and maturity in issues of death and dying.

This methodology was approved by the students, who assessed reflective agents and builders of personal and professional growth. The horizontality used provided moments of productive discussions and skills development, such as speech and listening, thus providing therapeutic moments.

It is also worth noting the satisfaction provided to the teachers when observing the individual growth of each student and the recognition of a successful practice.

\section{REFERENCES}

1. Waterkemper R, Prado ML. Estratégias de ensino-aprendizagem em cursos de graduação em Enfermagem. Av Enferm [Internet]. 2011 [cited 2018 May 2]; 29(2):234-46. Available from: http://www.scielo. org.co/pdf/aven/v29n2/v29n2a03.pdf

2. Santos MA, Hormanez M. The attitude among nursing professionals and students when facing death: a review of the scientific literature of the last decade. Ciênc Saúde Coletiva [Internet]. 2013; [cited 2017 Sep 11]; 18(9):2757-68. Available from: http://www.scielo.br/pdf/csc/v18n9/ v18n9a31.pdf

3. Bandeira D, Cogo SB, Hildebrandt LM, Badke MR. Death and dying in the formation process of nurses from the perspective of nursing professors. Texto Contexto Enferm [Internet]. 2014 Apr/Jun; [cited 2017 Sep 11]; 23(2):400-7. Available from: http://www.scielo.br/scielo. php?script=sci_arttext\&pid=S0104-07072014000200400

4. Nia HS, Lehto RH, Ebadi A, Peyrovi H. Death Anxiety among Nurses and Health Care Professionals: A Review Article. Int J Community Based Nurs Midwifery [Internet]. 2016 Jan; [cited 2017 Sep 10]; 4(1):2-10. Available from: https://www.ncbi.nlm.nih.gov/pubmed/26793726 
5. Vacek JE. Using a conceptual approach with concept mapping to promote critical thinking. J Nurs Educ [Internet]. 2009 Jan; 48(1):45-8. Available from: https://www.ncbi.nlm.nih.gov/pubmed/?term=Using+a +conceptual+approach+with+concept+mapping+to+promote+critical +thinking

6. Moreira MADM, Lustosa AM, Dutra F, Barros EO, Batista JBV Duarte MCS. Políticas públicas de humanização: revisão integrativa da literatura. Ciênc Saúde Coletiva [Internet]. 2015; [cited 2018 Mar 4]; 20(10):3231-42. Available from: http://www.scielo.br/pdf/csc/ v20n10/1413-8123-csc-20-10-3231.pdf

7. Lima R, Borsatto AZ, Vaz DC, Pires ACF, Cypriano VP, Ferreira MA. A morte e o processo de morrer: ainda é preciso conversar sobre isso. Rev Min Enferm [Internet]. 2017; [cited 2018 Apr 1];21:e-1040. Available from: http://www.reme.org.br/artigo/detalhes/1178

8. Barrows HS. Problem Based Learning Initiative. Springfield: Southern Illinois University School of Medicine [Internet]. 2017; [cited 2017 Sep 26]. Available from: http://www.pbli.org/core.htm
9. Ministério da Saúde (BR). Secretaria de Gestão do Trabalho e da Educação na Saúde. Departamento de Gestão da Educação na Saúde; Escola Nacional de Saúde Pública (Brasil). Curso de especialização em ativação de processos de mudança na formação superior de profissionais de saúde. Situações problema: especializando. Brasília (DF): Ministério da Saúde/FIOCRUZ; 2008. 43 p.

10. Prado ML, Velho MB, Espíndola DS, Sobrinho SH, Backes VMS. Charles Maguerez Arc: reflecting methodology strategies on active training for health professionals. Esc Anna Nery [Internet]. 2012 Jan/Mar; [cited 2017 Oct 15]; 16(1):172-7. Available from: http://www.scielo.br/pdf/ean/ v16n1/v16n1a23.pdf

11. Cogo ALP, Dal Pai D, Aliti GB, Hoefel HK, Azzolin KO, Busin L, et al. Case studies and role play: learning strategies in nursing. Rev Bras Enferm [Internet]. 2016; [cited 2017 Nov 6]; 69(6):1163-7. Available from: http:// www.scielo.br/pdf/reben/v69n6/0034-7167-reben-69-06-1231.pdf

12. Kloh D, Lima MM, Reibnitz KS. Compromisso ético-social na proposta pedagógica da formação em enfermagem. Texto Contexto Enferm [Internet]. 2014 Apr/Jun; [cited 2017 Oct 6];23(2):484-91. Available from: http://www.scielo.br/pdf/tce/v23n2/pt_0104-0707-tce-23-02-00484.pdf 